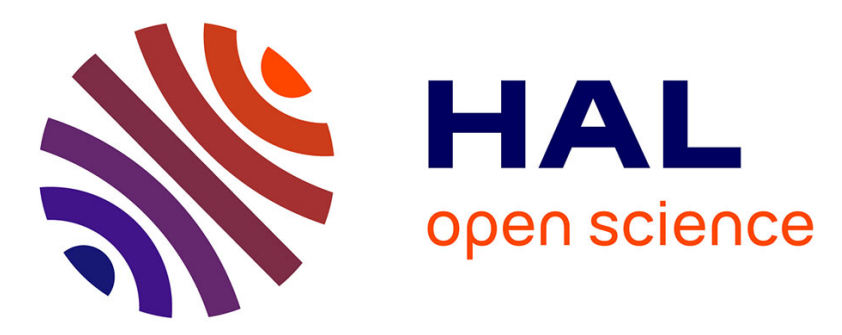

\title{
Mapping Contours of Reconciliation and Peace Process in Afghanistan: Policy Options for Pakistan
}

\author{
Muhammad Nadeem Mirza, Hussain Abbas, Ummul Baneen
}

\section{To cite this version:}

Muhammad Nadeem Mirza, Hussain Abbas, Ummul Baneen. Mapping Contours of Reconciliation and Peace Process in Afghanistan: Policy Options for Pakistan. Journal of Peace, Development and Communication, 2020, 4 (1), pp.1-22. 10.36968/JPDC-V04-I01-01 . halshs-02954683

\section{HAL Id: halshs-02954683 \\ https://shs.hal.science/halshs-02954683}

Submitted on 1 Oct 2020

HAL is a multi-disciplinary open access archive for the deposit and dissemination of scientific research documents, whether they are published or not. The documents may come from teaching and research institutions in France or abroad, or from public or private research centers.
L'archive ouverte pluridisciplinaire HAL, est destinée au dépôt et à la diffusion de documents scientifiques de niveau recherche, publiés ou non, émanant des établissements d'enseignement et de recherche français ou étrangers, des laboratoires publics ou privés. 


\section{Journal of Peace, Development and Communication}

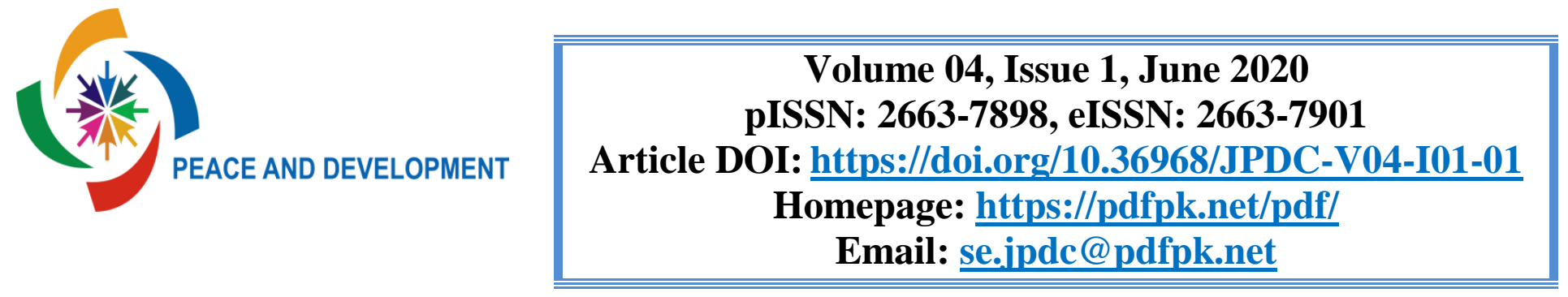

\begin{tabular}{|c|c|}
\hline Article: & $\begin{array}{c}\text { Mapping Contours of Reconciliation and Peace Process in Afghanistan: Policy } \\
\text { Options for Pakistan }\end{array}$ \\
\hline \multirow{3}{*}{ Author(s): } & $\begin{array}{l}\text { Dr. Muhammad Nadeem Mirza } \\
\text { Faculty Member, School of Politics and International Relations (SPIR), Quaid-i- } \\
\text { Azam University (QAU), Islamabad }\end{array}$ \\
\hline & $\begin{array}{c}\text { Hussain Abbas } \\
\text { Ph.D. scholar, School of Politics and International Relations (SPIR), Quaid-i-Azam } \\
\text { University (QAU), Islamabad }\end{array}$ \\
\hline & $\begin{array}{l}\text { Ummul Baneen } \\
\text { Assistant Professor, Arts and Media Department, Foundation University Islamabad, } \\
\text { Pakistan }\end{array}$ \\
\hline Published: & $30^{\text {th }}$ June 2020 \\
\hline Publisher Information: & Journal of Peace, Development and Communication (JPDC) \\
\hline To Cite this Article: & $\begin{array}{c}\text { Mirza, Muhammad Nadeem, et al. (2020). "Mapping Contours of Reconciliation } \\
\text { and Peace Process in Afghanistan: Policy Options for Pakistan.” Journal of Peace, } \\
\text { Development and Communication, vol. 04, no. 01, 2020, pp. 1-22, } \\
\text { https://doi.org/10.36968/JPDC-V04-101-01. }\end{array}$ \\
\hline \multirow{3}{*}{ Author(s) Note: } & $\begin{array}{l}\text { Dr. Muhammad Nadeem Mirza is serving as faculty member at School of Politics } \\
\text { and International Relations (SPIR), Quaid-i-Azam University (QAU), Islamabad }\end{array}$ \\
\hline & $\begin{array}{c}\text { Hussain Abbas is a Ph.D. scholar at SPIR QAU, Islamabad and Lecturer at } \\
\text { Department of International Relations, The Islamia University of Bahawalpur, } \\
\text { Bahawalpur }\end{array}$ \\
\hline & $\begin{array}{c}\text { Ummul Baneen is serving as Assistant Professor at Arts and Media Department, } \\
\text { Foundation University Islamabad, Pakistan }\end{array}$ \\
\hline
\end{tabular}




\begin{abstract}
Afghan war has long been considered as a strategic failure, as the US could neither bring an end to the violence, nor ensure complete territorial control. Deteriorating security situation has also endangered stability of adjoining states. With the failure of military means to resolve Afghan crisis, the need for a political solution gained momentum resulting in the US-Taliban agreement in early 2020. This study traces out why, despite various rounds of talks and initiatives of reconciliation and peace process, the successful stability could not be achieved in Afghanistan. The study concluded that all the stake-holders continued to pursue unrealistic objectives, resulting in failure of the previous efforts of peace talks.

Key Words: Reconciliation, Peace Process, Afghanistan, Taliban, United States, Pakistan, Clashing interest.
\end{abstract}




\section{Introduction}

On February 29, 2020, the United States and Taliban signed a deal which is considered as the beginning of the end of one of the longest wars in US history (Mashal, 2020). Afghanistan has remained unstable since the US-led invasion in 2001. Although the immediate objective of the invasion, that is, overthrowing the Taliban regime was achieved, yet the long-term objective of preventing Afghanistan from becoming a safe haven for terrorists having global orientation could not be achieved till today - remnants of Al-Qaeda and a reinvigorated ISIS is still active in Afghanistan. Besides, Taliban after abdication from power, adopted guerilla warfare as a means to challenge the US forces and US-supported government at Kabul. Resultantly neither terrorism nor insurgency could be eradicated from the state. Presence of the International Security Assistance Force (ISAF) comprising personnel from 44 to 52 states could not bring stability in Afghanistan. When ISAF ended its operations in 2014, most of Afghanistan was still not in the control of Kabul (Giustozzi, 2018; Tisdall, 2018).

One of the major causes of failure of the international forces to bring stability in Afghanistan remained adopting 'military' means to bring peace. But, since the appointment of Richard Holbrook as President Obama's Special Representative for Afghanistan and Pakistan, efforts have been strengthened to stabilize the situation in Afghanistan through both military as well as non-military means (Harnden, 2010). But due to divergence of interests and objectives between the involved actors, those efforts could not bring desired results. Rather deadlocks and uncertainty prevailed through most of the times. Less faith towards the utility and feasibility of talks, and mistrust among the actors remained the main issues of concerns.

In September 2018, President Trump appointed Zalmay Khalilzad - an astute diplomat having immense experience of working on the hot seats - as US Special Representative for 
Afghan Reconciliation. Being an Afghan born US citizen, he immediately embarked upon the uphill task of building rapprochement with the Taliban and other actors, and gave a clear message to everyone that this time the United States is determined to sign a formal agreement (Mashal \& Jakes, 2020). Resultantly faith in the utility of the talks developed and within one month i.e. in October 2018 Pakistan freed Mullah Abdul Ghani Barader - one of the founders of Taliban movement - from jail. He later joined the Taliban political office in Doha, as its head negotiator. About one and half years of talks between the two resulted into a formal agreement signed in February 2020.

Both the United States and Taliban downgraded their previous positions and tried to achieve realistic objectives this time. For example Taliban have continuously been refusing to hold talks with the Afghan government considering it to be a puppet of the western forces. But as part of the agreement, it agreed to hold intra-Afghan dialogue. Sirajuddin Haqqani, Taliban's deputy leader, notes in an op-ed he'd written for the New York Times, "We are conscious of the immense challenges ahead. Perhaps our biggest challenge is to ensure that various Afghan groups work hard and sincerely toward defining our common future. I am confident that it is possible. If we can reach an agreement with a foreign enemy, we must be able to resolve intraAfghan disagreements through talks (emphasis added)" (Haqqani, 2020).

The United States, on the other hand, agreed to reduce the number of forces from 12,000 to 8,600 in 135 days. And if the Taliban continues to honour their part of the deal, all the foreign forces will be withdrawn within fourteen months (Maizland, 2020). It seems that the United States again has agreed to an unrealistic objective of complete withdrawal of the foreign forces from Afghanistan, to appease Taliban and formalize an agreement with them - this being their first and foremost demand. Because American public has grown wary of the Afghan war being 
one of the longest and having costed more than \$2 Trillions, with thousands of casualties. President Trump has made a campaign promise to end Afghan war. There is no doubt that he will use this agreement as a success story for his upcoming election campaign. Complete withdrawal of Americans from Afghanistan is unrealistic because it might create a situation similar to the 1990s when several Afghan factions started a civil war after the US withdrawal. Besides strategically the US complete withdrawal will create a power vacuum in Afghanistan which could be filled by other great powers lying in Afghanistan's vicinity. So it is unexpected that the United States will completely withdraw its troops from Afghanistan, and will remain engaged even if complete peace and stability is achieved therein. The United States has made complete withdrawal conditional and dependent upon the Taliban behavior. President Trump, after the agreement, said "I really believe the Taliban wants to do something to show that we're not all wasting time ... If bad things happen, we'll go back ... we'll go back with a force like nobody has ever seen" (Trump, 2020).

Agreement also talks about the proposed alignment - not a formal alliance - of their interests vis-à-vis Daesh (Islamic State of Khorasan Province) and other terrorist organizations such as Al-Qaeda. The Taliban ensured that they will fight and will not let terrorists, having global ambitions and wishes to target American interests and use Afghanistan as a sanctuary. President Trump pronounced, "They will be killing terrorists. They will be killing some very bad people. They will keep that fight going" (Trump, 2020). It is believed that ISKP has been responsible for some of the worst attacks against the civilian population in Afghanistan in recent times. Magnitude of the violence has even forced the Taliban to denounce the acts. Taliban have already been fighting against ISKP in Afghanistan and vowed to end ties with Al-Qaeda and other international terrorist organisations. 
The United States also agreed to lift sanctions against Taliban and also to help the United Nations in lifting sanctions it had imposed on Taliban. Idea is to help the Taliban in their transformation from a military organization to one who can participate constructively in the Afghan political process. The most important part of the agreement remained intra-Afghan dialogue. President Ghani has been facing a legitimacy crisis because of the allegations by his political opponent Abdullah Abdullah that he has rigged the presidential elections. Taliban have long refused to hold formal talks with the Afghan government. Afghans outside of Kabul have least trust in the Afghan government considering it to be corrupt, inept, and incapable of providing basic facilities to the population. Taliban on the other hand have established shadow governments in several areas of Afghanistan and according to a report by "the Special Inspector General for Afghanistan Reconstruction (SIGAR), as of January 31 last year (i.e. 2018), 229 districts were under the Afghan government's control, which is about 56.3 percent of the total Afghan districts" (Chughtai, 2019). Other areas are either being controlled by Taliban or are considered as contested areas with differing claims (See figure 1). Situation is further complicated because of the presence of other warlords such as Gulbuddin Hekmetyar and Abdul Rasheed Dostum, who still have sway in their respective areas of influence and are in agreement with the sitting government. Sectarian and ethnic differences have long fueled conflicts between different Afghan sections of the society. ISKP and other terrorist groups would not like to see a stable Afghanistan because it will reduce their maneuverability.

Above all, the role of the external actors will remain important to influence the domestic political processes. In such a situation achieving an intra-Afghan longstanding and enduring peace agreement is a complicated and a herculean task. Pakistan recently appointed Muhammad Sadiq, who has served as Pakistan's ambassador in Kabul from 2008-14, as Special 
Representative for Afghanistan (Ministry of Foreign Affairs Pakistan, 2020; Shabbir, 2020). Soon after his appointment he has started meeting with different Taliban and Afghan government officials in order to facilitate their dialogue. Reaching an agreement, though, a task that is difficult to achieve but still possible if the actors involved are ready to compromise compromise being an understanding or an agreement where every involved actor sacrifices some part of its interest in order to achieve the greater good.

\section{Taliban Control in Afghanistan}

Control by district, as of February 2020

Taliban control

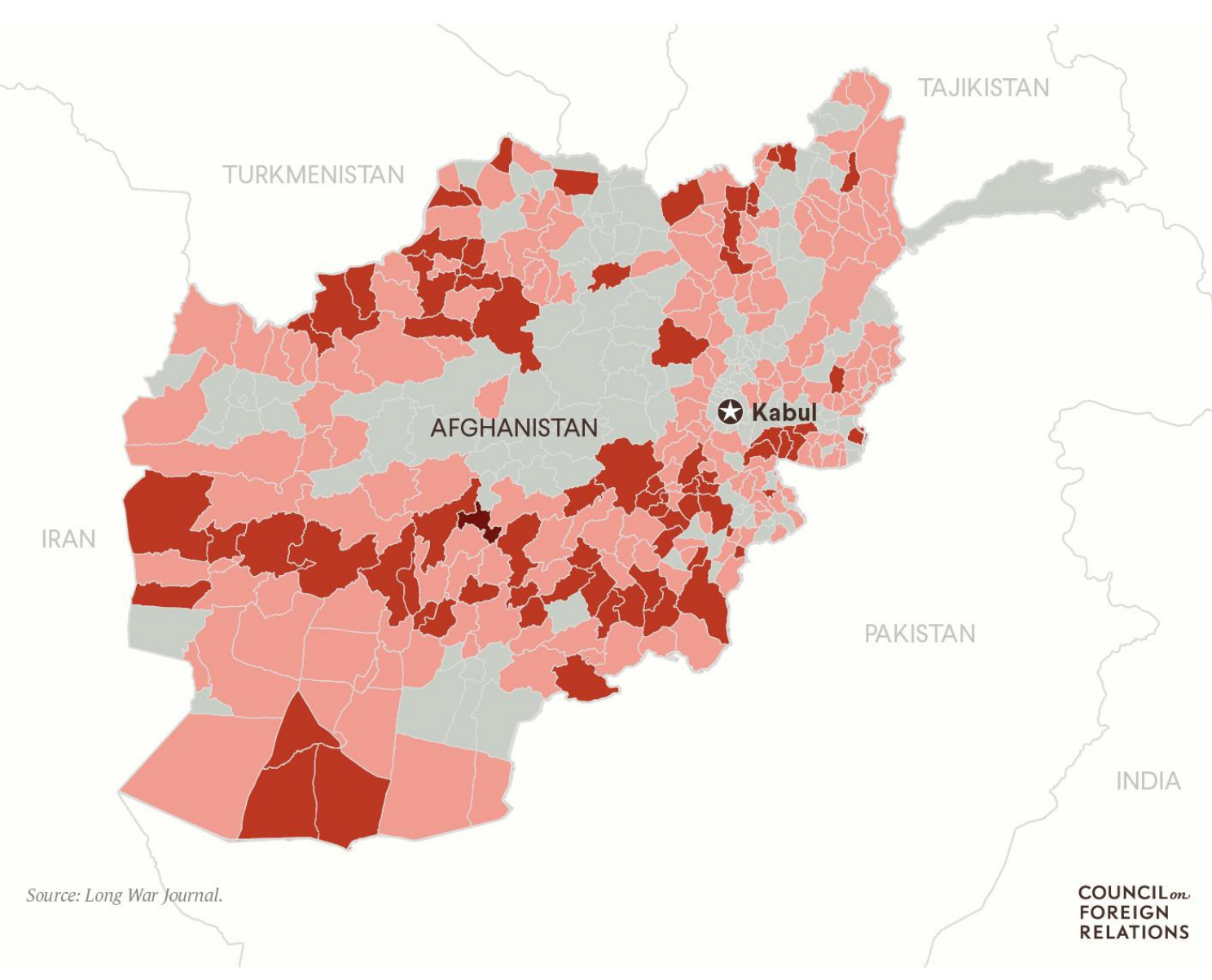

Figure 1: Territorial control of Afghanistan (Source: Long War Journal, through Council on Foreign Relations). 
Efforts to achieve peace through negotiation is not a new phenomenon in Afghanistan. Afghan government and the US have pursued several initiatives of reconciliation and peace talks with insurgent groups, since 2010. President Ashraf Ghani, specially, has made several offers to Taliban for sitting together in order to reconcile for the future of Afghanistan. Despite having several rounds of talks and initiatives, even an agreement between the Taliban and the US, achieving stability and peace still remained an uphill task. The biggest challenge has been the entrenched mistrust between the involved actors. Pakistan was initially marginalized and kept out of the talks. This further complicated the situation and increased the level of mistrust among the local and regional actors. In the most recent talks with Taliban, Pakistan was engaged and kept into confidence by the United States, resulting in a formal agreement. This paper attempts to dissect and map the intricate history of the Afghan peace and reconciliation process.

\section{Background of the Reconciliation Efforts}

Worsening security situation and complexity of Afghan conflict and its antecedent repercussions - such as ascending cost in economic terms, social damage and human sufferings has forced the international community especially the United States to pursue political options to resolve the issue. A reconciliation, reintegration and peace initiative (in terms of peace talks and deal) was thus expedited. Various efforts have been made by Afghan government, international community, and some regional stakeholders to reintegrate insurgents into the social and political fabric of Afghan society but such efforts have failed due to the lack of coordinated and comprehensive peace and stabilization strategy.

Initially, there was no coherent policy regarding the reconciliation or a process of peacemaking. The conviction that moderate Taliban should be engaged in the political process of Afghanistan has strongly been favored by Pakistan and this conception was initially adopted by 
Afghan government as well. Immediately after the US invasion of Afghanistan, 'President Musharraf talked about the importance and necessity of working with moderate elements inside the Taliban'(Rashid, 2008, pp. 72-73). Although this Pakistan's wish may be regarded as a move for the sake of its own strategic interests, this was a balanced approach; US has realized it very recently.

Because of its hard past, Pakistan was forced to hesitate to fully trust the US. During the 1990s, the United States - after achieving its objective of Soviet withdrawal from Afghanistan had literally left Pakistan to deal with a plethora of challenges in the form of millions of migrants, abundance of freely available weapons, a chaotic neighbor - Afghanistan - ravaged with the civil war. Above all it imposed military and economic sanctions on Pakistan that furthered the already dire situation in the region, resulting in widening the trust gap between the two. The United States also remained suspicious of the role of Pakistan in Afghanistan, especially in the post 9/11 era. It accused Pakistan of playing a 'double game' in Afghanistan, thus threatening the American interests therein (Millar, 2011).

\section{Developments in Reconciliation and Peace Talks since 2010}

Concerted efforts to pursue a peace process were launched in 2010, when Afghan government, with the help of Saudi Arabia, tried to directly reach out to the Taliban. In this attempt, Pakistan was deliberately kept out of the peace process. Pakistan, after such moves on the part of Afghan government and the US, maneuvered to reassert its role and convinced the actors about its pivotal importance in the peace process. The arrest of Mullah Abdul Ghani Bradar (Mazzetti \& Filkins, 2010) was considered as a move in this regard, because he was considered as one of the most influential Taliban negotiator - one of the co-founder of Taliban 
movement along with Mullah Umer - having contacts with the UN, Afghan government, and even with the Saudi and American intelligence agencies.

In mid 2010, Afghan government launched National Peace Conference also known as Peace Jirga (Wadhams, 2010). President Karzai pleaded Taliban to join the negotiation process and also offered to set aside preconditions for talks, previously set by the US government. Although various other concessions were offered to the Taliban, but they could not be attracted to the negotiations and increased their attacks throughout Afghanistan, including on the peace gatherings (CNN Wire Staff, 2012b).

Increase in insurgency met with renewed military operations in the insurgent strongholds. These counter insurgency operations were effective in limited sense, by eliminating lower level office bearers of Taliban, but in general these operations remained a failure with no significant decline in insurgency or betterment in the law and order situation. This further enhanced the need for a comprehensive peace process. In the meantime, the US also took initiatives to hold peace talks with various insurgent groups, and accelerated its efforts to contact Taliban. It was reported that American officials - with the facilitation of Pakistan - had participated in meetings with high level Taliban officials, in Germany and Qatar, and was regarded as a trust building move between Pakistan and the US on the issue (Bew et al., 2013, p. 32).

\section{Positive Shift: Qatar Negotiation Process}

By the end of 2011, the United States showed commitment to the profound peace process to settle the political and security issues in Afghanistan. It was decided to comprehensively start peace talks with the Taliban. It was also an indication that all the groups of Taliban would be engaged in the peace process with varying degrees of interests and objectives. The Second Bonn conference on Afghanistan in 2011 can be mentioned in this regard. In this conference an Afghan 
led peace process was suggested. Vice President Joe Biden, went to the extent of exclaiming that Taliban per se are not our enemy and spoke explicitly of the administration's desire to bring about a reconciliation that would include them (Bew et al., 2013, p. 34).

Although, Karzai government supported talks with the Taliban, yet the matter of opening the Taliban's office in Qatar complicated the situation and Afghan government showed concerns regarding the developments in the reconciliation and peace talks. President Karzai, even, attempted to initiate his own strand of dialogue with the Taliban, separate from the American one (Sommerville \& Sarwary, 2012). Taliban showed reservations in engaging in peace talks with the Karzai government. In February 2012 Taliban spokesman informed a TV channel that Taliban would not hold talks with Karzai government because it 'is a puppet and unauthorized, and meeting with them will not be beneficial in solving the issue ... everyone around the world knows that the one who has got the authority in opposition to the Mujahideen (the Taliban) is America' (N. P. Walsh \& Popalzai, 2012). By this statement Taliban clearly indicated that they would only meet with the US official, considering them to be the real decision makers in Afghanistan.

With a brief period of positive developments in the peace talks, differences surfaced on various levels from different concerned parties that led to the suspension of the talks in Qatar. This phase of the peace talks can be regarded as a half-hearted effort because serious measures were not adopted to win the confidence of the parties. Taliban wanted the US to withdraw international troops from Afghanistan; while renouncing violence by Taliban and showing a firm commitment to the peace process was the main condition that was put up by the US (CNN Wire Staff, 2012a). 


\section{Suspension of Talks: A Setback to Afghan Peace Process}

In an environment of confusion and mistrust Taliban announced the suspension of talks and peace negotiations with the Americans (Clark, 2012). Reasons for deadlock were numerous: those having their roots in Afghan government and Taliban hostility, between the US and Taliban, and some reason were of regional in nature. The most crucial factor was the release of Taliban officials and their representation in Taliban office in Qatar. US relations with Pakistan also got tense as a result of US forces' attack on Pakistan's Salala check-post that killed 24 Pakistani soldiers. Pakistan, in response, suspended all the initiatives of facilitation for the US, suspended NATO supply, and denied visas to US diplomats engaged in peace talks with Taliban.

This was a setback to the negotiations process as Pakistan was playing a vital role as a facilitator. Suspicious of US attitude, Pakistan vacillated considerably between being a facilitator and opponent to the talks. It has pressed Taliban to hold peace talks with Afghan government (D. Walsh \& Schmitt, 2012), while at other times it considered 'preposterous' and 'ridiculous' to demand Pakistan of encouraging senior Taliban leadership to come on the negotiation table (Abbot, 2012) - this statement specifically was issued in the aftermath of the Salala incident.

\section{Doha Peace Talks: From Hope to Dismay}

2013 Doha process could not proceed and a deadlock occurred over the 'title of Islamic Emirate of Afghanistan and flag used by Taliban for their office' (Hussain, 2013). This move on part of Taliban was viewed by Afghan Government with great suspicion and regarded it as tantamount to Taliban government in exile (Hussain, 2013). After more than a year of suspension of talks, a series of diplomatic and secret efforts were started by the US and other NATO members, backed and endorsed by Pakistan to convince Taliban to come back to the negotiation table. Taliban were allowed to re-open their political office in Qatar in 2015 (Bakr \& Ahmad, 
2015). Pakistan by playing a crucial role in the peace talks between Taliban and the United States expected that all the parties will respect its strategic and political interests in Afghanistan.

\section{President Ashraf Ghani and efforts for peace}

With the new election and a government led by President Ashraf Ghani, an initiative of peace talks and reconciliation was launched more enthusiastically. Ghani government officially made reconciliation and peace talks a prime agenda for its initial domestic policies. After a series of diplomatic and political discussions, persuasion, and maneuvering partly on the part of US and Afghan governments, and mainly by Pakistan, Afghan government and Taliban got ready to start negotiations for a political solution of Afghan issue.

\section{Murree Process: A Casualty of Death of Mullah Umer and Mullah Mansoor}

The new process for peace and stability in Afghanistan started at Murree, in the outskirts of Islamabad on July 7, 2015. Facilitated and hosted by Pakistan, this initiative gained the support and participation of major stakeholders. This process, known as 'Murree Process,' was hailed and optimized by participants and analysts. It was regarded as a decisive process that would yield profound results. An agreement was anticipated. But the process suffered a major setback as day before the second round of major talks, it was revealed that Mullah Umer, supreme leader of Taliban, had died in 2013 (T. Khan, 2015; Staff Reporter, 2015). It is believed that Afghan government leaked the news of Mullah Umer's death, as it was unhappy with this process being held in Pakistan. It changed the ground situation altogether. Talks were suspended and the struggle for succession in the Taliban leadership had thrown the peace process into uncertainty.

New Taliban leader, Mullah Akhtar Mansoor, previously known as a person in favor of talks, hardened its stance against the peace process and determined to continue violence in order 
to achieve their objectives (Osman, 2015). Under new realities and compulsions, he not only negated holding the peace talks, but also called it as enemies' propaganda. It seemed that he took this hard stance to win the sympathy of most of the Taliban members, to consolidate his position for leadership and to end friction between Afghan Taliban.

On May 22, 2016 Mullah Mansoor was killed in a drone attack near Afghan border in Balochistan, Pakistan. This was a tragic event as it obstructed the negotiation process that had been launched with the help of Pakistan. Pakistan regarded it as an attack on Afghan peace process and also an act against its sovereignty (Zia, 2016). NATO Secretary General also regarded this act a negative one that has 'obstructed the peace talks between the movement and the Afghan government, holding back the peace process' (Zia, 2016).

\section{Quadrilateral Coordination Group and Peace Process}

Reconciliation and peace building is not an event, it is a process and it occurs through a series of diplomatic and political ventures by different stakeholders. Reconciliation and talks with Taliban was a daunting task, therefore major stakeholders established the Quadrilateral Coordination Group (QCG) consisting of two major powers, the US and China; and two immediate stakeholders, Afghan government and Pakistan. This arrangement of a group, focused on the political solution of Afghanistan and especially on peace talks with Taliban, regarded as a novel idea and a necessary development. First meeting of the QCG was held on January 11, 2016. 'The meeting ... underlined the strong commitment of a government of Afghanistan for peace and reconciliation with Taliban groups and Hezbi Islami Hekmatyar' (Z. Khan, 2016). Addressing the second meeting of QCG Afghan Foreign Minister Salahuddin Rabbani invited the Taliban on behalf of the government of Afghanistan and the people of Afghanistan to join the peace process and solve all differences through negotiations (Z. Khan, 2016). 
Although formation and working of QCG is regarded as an important and a valuable platform for the reconciliation and peace process, yet it is also an evident fact that Taliban did not joined this group and levied conditions to hold direct talks with the US only. In this backdrop, President Trump got elected in the US with a determination to achieve an agreement with Taliban, and bring an end to the US active involvement in Afghanistan. He nominated Zalmay Khalilzad as his special advisor on Afghanistan, with the 'singular' objective of reconciling Afghan government and Taliban, and to bring an end to Afghan crisis (AFP, 2018). Soon after his appointment he established contacts with Taliban, Afghan government, and also visited Islamabad with a letter from President Trump seeking Pakistan's help in bringing an end to Afghan crisis (Constable, 2018).

\section{Policy Options for Pakistan}

Keeping into consideration the dynamic nature of recent political game in Afghanistan and processes for the establishment of peace and stability in Afghanistan, Pakistan has the cause and capacity to play an influential role at policy level. Pakistan has to consciously choose policy options vis-à-vis Afghanistan because any policy move taken in haste without exhaustive consideration of alternatives would be dangerous for Pakistan and will have long-term consequences.

First, Pakistan shares a long border with Afghanistan that can be an asset with regard to its dealings with Afghanistan. Chinese, American, and Russian interests in Afghanistan alongwith materialization of China Pakistan Economic Corridor (CPEC) have made geo-strategic position of Pakistan more important. Considering it as an advantage over other regional players Pakistan can convince international actors for the necessity of peace and stability and, its role and interests linked with the future political settlement in Afghanistan. Pakistan should not 
pursue passive engagement, rather should play an important frontline role in Afghanistan especially with regard to establishment of peace and stability.

Second, there is a pervasive conviction that Pakistan has massive reach and influence over the Taliban. Regional players, the US and international community have realized this fact. Pakistan's recognition as a crucial state for the political solution of Afghanistan puts some responsibility and provides some opportunity for Pakistan. Keeping in mind the best opportunity and important responsibility Pakistan should devise such a policy that balances its interests with that of Afghan government, international community, and regional powers. Pakistan should try to convince the Taliban that after reaching an agreement with the US, it should also pursue peace talks with Afghan government diligently. Stability should be the prime objective among Pakistan's strategic stakes in Afghanistan because instability and complexity of civil war would resultantly destabilize bordering areas in Pakistan and would sabotage the hard-earned results of war against terrorism. Pakistan should respect other states' interests but should not compromise its vital security interests.

Third, Trump presidency did not augur well for Pakistan in the beginning. But with the passage of time President Trump's tone vis-à-vis Pakistan changed and he adopted a more compromising approach. With the help of Pakistan, the United States has achieved the objective of signing a deal with Taliban. Elections will be held in November in the United States, and President Trump will try to utilize this achievement as his major rallying point. But if President Trump gets re-elected, he would be more free to pursue policies independent of domestic constraints. He may change his tone and stance vis-à-vis Pakistan and Afghanistan - considering him to be a half-tempered person. And even if he loses and Joe Biden wins the election, then what will be his policy choices vis-à-vis Pakistan and Afghanistan. These are very important 
considerations that Pakistan has to weigh before moving any further in the Afghan reconciliation process. What if making excuses for the violence in Afghanistan, President Trump re-starts active military engagement with Afghanistan.

Fourth, Indian lobby in the United States, Indian influence over Afghan government, and its activities inside Afghanistan against Pakistan's interest also need to be taken into consideration. A stable, peaceful, and friendly Afghanistan is in the best interest of Pakistan. But whether it is also in the best interest of India is a big question. A weak and fragmented Afghanistan gives an opportunity to India to exploit the ground situation, and apply economic and political leverage against the central government.

\section{Conclusion}

In the wake of the deteriorating security situation in Afghanistan, urgency for political solution gained impetus. Throughout the Bush Administration, major focus remained on the military solution of Afghan crisis. The Obama administration tilted towards negotiations and talks but initiatives resulted in despair because of mistrust, lack of feasible environment, and inflexibility of the demands of the parties concerned. Although the idea of engaging Taliban in the reconciliation process was proposed by Pakistan in the early years of US invasion but it was neglected. President Musharraf even before the invasion of Afghanistan gave a message to the US in these words "We need to think about the political future of Afghanistan."

The Most difficult phase of the peace process, that is, getting Taliban, Afghan government, and other domestic actors to reach some agreement has already started. In 2016 signing of the a deal between Afghan government and Gulbuddin Hekmatyat of Hizb-e-Islami is another such example where a successful peace agreement was achieved ('Afghan Warlord Hekmatyar Returns to Kabul after Peace Deal', 2017; Rasmussen, 2016). But one thing is for 
sure that Afghans themselves have a very little chance of reaching an agreement independently. They need support and pull and push by the international actors. This support can be provided by Pakistan, the United States, China, Russia, and may be even Iran. For its part, Pakistan has been playing a highly constructive role. Appointment of Mohammad Sadiq as Special Representative for Afghanistan for the first time since the start of the war informs about the seriousness at its part.

Pakistan must carefully evaluate the available policy options, instead of making a decision in haste, so as to minimize the long-term costs and gain maximum benefits. Best thing to do will be to take other regional and extra-regional powers on board and pursue a concerted policy vis-à-vis Afghanistan - though still a distant dream. 


\section{References}

Abbot, S. (2012, February 17). Pakistan: It's 'preposterous' we could bring Taliban chief to talks. Christian Science Monitor. https://www.csmonitor.com/World/Latest-NewsWires/2012/0217/Pakistan-It-s-preposterous-we-could-bring-Taliban-chief-to-talks

Afghan Warlord Hekmatyar returns to Kabul after Peace Deal. (2017, May 4). BBC. https://www.bbc.com/news/world-asia-39802833

AFP. (2018, September 5). Zalmay Khalilzad: The blunt veteran US diplomat leading peace efforts in Afghanistan. Dawn.

Bakr, A., \& Ahmad, J. (2015, May 4). Afghan talks agree on reopening Taliban political office. Reuters. https://www.reuters.com/article/us-qatar-afghanistanidUSKBNONO0M920150504

Bew, J., Evans, R., Frampton, M., Neumann, P., \& Porges, M. (2013). Talking to the Taliban: Hope over History? The International Centre for the Study of Radicalisation and Political Violence - ICSR.

Chamberlin, W. J. (2001). Telegram from US Embassy Islamabad to Department of State: Musharraf Accepts Seven Points. US Department of State.

Chughtai, A. (2019, June 24). Afghanistan: Who controls what. AlJazeera. https://www.aljazeera.com/indepth/interactive/2016/08/afghanistan-controls160823083528213.html

Clark, K. (2012, March 16). The End of the Affair? Taleban Suspend Talks. Afghanistan Analysts Network - AAN. https://www.afghanistan-analysts.org/the-end-of-the-affairtaleban-suspend-talks/ 
CNN Wire Staff. (2012b, September 26). Drone strikes kill, maim and traumatize too many civilians, U.S. study says. $C N N$.

Constable, P. (2018, December 3). Trump sends letter to Pakistan asking for help with Afghan peace process. Washington Post.

Giustozzi, A. (2018). The Islamic State in Khorasan: Afghanistan, Pakistan and the New Central Asian Jihad. Hurst.

Haqqani, S. (2020, February 20). What We, the Taliban, Want. The New York Times. https://www.nytimes.com/2020/02/20/opinion/taliban-afghanistan-war-haqqani.html

Harnden, T. (2010, December 14). Richard Holbrooke's last words: 'You've got to stop this war in Afghanistan'. Telegraph.

Hussain, S. (2013, July 28). Doha deadlock putting Afghan peace efforts at stake. Pakistan Today.

Khan, T. (2015, September 2). Death of Mullah Omar death dashes hopes of peace with Taliban. The National. https://www.thenational.ae/world/death-of-mullah-omar-death-dasheshopes-of-peace-with-taliban-1.128541

Maizland, L. (2020, March 2). U.S.-Taliban Peace Deal: What to Know. Council on Foreign Relations, Backgrounder.

Mashal, M. (2020, February 29). Taliban and U.S. Strike Deal to Withdraw American Troops From Afghanistan. The New York Times. https://www.nytimes.com/2020/02/29/world/asia/us-taliban-deal.html

Mashal, M., \& Jakes, L. (2020, March 1). At Center of Taliban Deal, a U.S. Envoy Who Made It Personal. The New York Times. https://www.nytimes.com/2020/03/01/world/asia/zalmaykhalilzad-afghanistan-taliban.html 
Mazzetti, M., \& Filkins, D. (2010, February 15). Taliban's Military Chief, Mullah Baradar, Is Captured. The New York Times.

Millar, D. (2011, May 11). Why Pakistan Plays a Double Game. Huffington Post. http://www.huffingtonpost.com/david-millar/why-pakistan-plays-a-doub_b_860184.html

Rashid, A. (2008). Descent into chaos: The US and the disaster in Pakistan, Afghanistan, and Central Asia. Penguin Books.

Rasmussen, S. E. (2016, September 22). 'Butcher of Kabul' pardoned in Afghan peace deal. The Guardian.

Shabbir, S. (2020, June 6). Pakistan appoints special envoy for Afghanistan. Arab News. https://arab.news/p2hdk

Sommerville, Q., \& Sarwary, B. (2012, January 29). Karzai 'plans talks with Taliban'. BBC. https://www.bbc.com/news/world-asia-16779547

Staff Reporter. (2015, July 31). FO announces postponement of second round of Afghan peace talks. Dawn.

Tisdall, S. (2018, August 1). Islamic State attacks show group is intent on killing Afghan peace hopes. The Guardian.

Trump, D. (2020, February 29). Remarks by President Trump, Vice President Pence, and Members of the Coronavirus Task Force in Press Conference: President's Remarks about Deal with Taliban. https://www.whitehouse.gov/briefings-statements/remarkspresident-trump-vice-president-pence-members-coronavirus-task-force-press-conference2/

Wadhams, C. (2010, June 4). Afghanistan's fluffy peace jirga. Foreign Policy. https://foreignpolicy.com/2010/06/04/afghanistans-fluffy-peace-jirga/ 
Walsh, D., \& Schmitt, E. (2012, February 24). Pakistanis Press Taliban to Start Talks With Afghans. The New York Times.

Walsh, N. P., \& Popalzai, M. (2012, February 14). Taliban will not talk peace with Karzai $\begin{array}{llll}\text { government, } & \text { spokesman } & \text { says. }\end{array}$ https://www.cnn.com/2012/02/14/world/asia/afghanistan-taliban/index.html

Zia, H. (2016, May 24). The Impact of Mansour's Death on Peace Talks. Daily Outlook Afghanistan. http://outlookafghanistan.net/topics.php?post_id=15339 